\title{
sciendo
}

Folia Oeconomica Stetinensia

Volume 20 (2020) Issue 2

DOI: $10.2478 /$ foli-2020-0040
WYDZIAL NAUK EKONOMICZNYCH I ZARZA_DZANIA

\section{CONSUMERS ENGAGEMENT TOWARD FOOD BRANDS - THE CASE OF DAIRY PRODUCTS}

\author{
Michał Gazdecki, Ph.D. ${ }^{1}$ \\ Elżbieta Goryńska-Goldmann, Ph.D. ${ }^{2}$ \\ Poznan University of Life Sciences \\ Faculty of Economics \\ Department of Economics and Economics Policy in Agribusiness \\ Wojska Polskiego 28, 60-637 Poznań, Poland \\ ${ }^{1}$ e-mail: michal.gazdecki@up.poznan.pl \\ ORCID: 0000-0002-6594-5350 \\ ${ }^{2}$ e-mail: gorynska@up.poznan.pl \\ ORCID: 0000-0002-0884-4772
}

Received 25 January 2020, Accepted 20 March 2020

\begin{abstract}
Research background: As food markets continue to develop the role and position of food consumers evolve as well. Food producers redefine their market strategies and focus on creating loyalty, building good contacts and consumers' engagement towards brands.

Purpose: The purpose of this paper is to analyze the engagement of consumers towards selected food brands in the category of dairy desserts.

Research methodology: The paper was prepared and based on the data collected in the survey among 200 respondents. The research subjects were consumers who declared the consumption of milk based desserts and the object of analyses was consumers' brand engagement considered at the behavioral level.

Results: Consumers with the opportunity to interact with a brand increase their propensity to recommend, which is a necessary condition for creating a reference market. As for the smaller companies, gaining sales growth through distribution and promotional activities may be difficult due to budget constraints, actions aimed at creating a reference market may be more effective.

Novelty: Although the issue of consumer engagement is an important area of scientific work, there is less interest in this field in the context of food markets. This paper provides additional knowledge about the context of food market products, which should be continued in further research. Based on our results, marketing strategies, mainly for a SME's, can be developed.
\end{abstract}

Keywords: consumers' behavior, relationships, B2C market, brand strategy

JEL classification: D12, D81, D91, M31 


\section{Introduction and goal of the paper}

The dynamic growth of food markets is manifested; among else, by redefining the way consumers are perceived in these markets. Whereas in the last century they mainly were passive participants, who either accepted or rejected the manufacturers' offers, they are now treated as an important element of the value network and actively participate in creating it. Companies are also subject to redefinition, who, apart from the task of ensuring satisfaction, primarily focus on creating loyalty, building good contacts and engaging in integrated communication (Gazdecki, Goryńska-Goldmann, 2018). Hence the importance of the analysis of engagement, which is strongly embedded in the relation paradigm and the consumers are seen as active participants of interactions between them and brands Vivek, Beatty and Morgan (2012).

Dairy products are a significant part of the food market in Poland. However, for the last 10 years, we might indicate changes in the whole dairy sector and consumption patterns. As Seremak-Bulge (2015) stressed the dairy processing industry was facing increasing competition from global markets, especially after and challenges related to the cancellation of milk quotas. At the same time, Polish consumers have been changing their consumption patterns - reduced milk consumption while keeping up cheese and dessert intake. Additionally, the share of dairy products expenditures decreased from $15 \%$ in 2010 to $13 \%$ in $2019^{1}$ which means, that this segment developed slower compared to the whole of the food products market. Such market conditions force dairy producers and trade companies to focus on consumers and build and reorganize brand strategies to continue the development of their market performance.

The purpose of this paper is to analyse the engagement of consumers towards selected food brands in the category of dairy desserts. The paper's first part reviews the literature on relation marketing and the engagement of consumers in food markets. The second part presents the results from the authors' own research.

\section{Relationship marketing and the essence of $\mathrm{B} 2 \mathrm{C}$ relationships}

Marketing has evolved with changes in the economic reality and market conditions that impact companies. Especially the 1980s were a period when we could observe the switch from the "traditional" transaction marketing to relationship marketing. It was when the Nordic model emerged which evolved from the relationship theory. That was an alternative for the AngloSaxon model which is based on the transactional paradigm. Relationship marketing is connected

\footnotetext{
1 Data based on:Rynek Wewnętrzny. GUS, Warszawa 2010-2020.
} 
with services marketing - which because of the non-physical nature of products focuses on long-term relations that can exist between all participants of a transaction. It also focuses on interaction streams, values treated as the subject of exchange, integration of marketing with other aspects of management and increasing the number of qualitative research (Gummesson, 1997; Mitręga, 2006).

One of the most commonly quoted definitions of relationship marketing was created by Grönroos (1997). It says that: relationship marketing is to establish, maintain and enhance relationships with customers and other partners, at a profit so that the objectives of both parties involved are met. This is achieved by a mutual exchange and keeping of promises. Such relationships are usually but not necessarily always long term.

The relationship parading of marketing, which emerged at the end of the $20^{\text {th }}$ century, had a lot of both supporters and opponents. However, it was attributed with the following possibilities of development (Sheth, Parvatiyar, 1995):

- it connected marketing theoreticians with different research centers,

- its broad scope made it possible to integrate different marketing subdisciplines,

- its creation was proof of the scientific nature of marketing, which as any other science can undergo the processes of development and creation of new theoretical constructs,

- many supporters of transactional marketing got interested in it.

As Sheth and Parvatiyar (1995) highlighted, in transactional marketing we mainly focus on the independence of different participants. In relationship marketing, market targets are achieved through cooperation, while agreeing to the limitation, to some scope, of that independence.

The central component of relationship marketing is a relation. Its scientific analyses refers to the social exchange theory which according to Emerson (1976, p. 336) is the economic analysis of noneconomic social situations. The source of relationships are social interactions (Fiske, 1992) and a relationship can be defined as: a mutually oriented interaction between two reciprocally committed parties (Håkansson, Snehota, 1995, p. 25).

There are many types of relationships (Gummesson, 1994) linked to the economy and management. In the context of market we may list the following relationships categories (Iacobucci, Hibbard, 1999)2 , among which there are B2C relationships which include relationships between an organization and individual consumers. Such a kind of relationship is often connected to the loyalty of consumers towards a brand which results in repeating some purchase decisions. Despite that, we should remember that repeated purchase decisions can have

\footnotetext{
2 They are: business marketing relationships (BMRs), interpersonal commercial relationships (ICRs), and business to consumers relationships (B2C).
} 
a different nature (Mitręga, 2006), i.e. they can result from some limitations (a consumer has no alternative and has to make the same purchase decision) or engagement (a consumer wants to stay in a given relationship). Both the abovementioned reasons can lead to sustain relationships, but the quality of such relationships should be interpreted in a different way (Bendapudi, Berry, 1997; Mitręga, 2006).

A specific feature of a $\mathrm{B} 2 \mathrm{C}$ relationship is the lack of symmetry in a consumer - company relation (Iacobucci, Hibbard, 1999) this creates a number of challenges concerning the management of such relationships. Non-comparable market power is the source of potential conflicts and the initial lack of trust (Iacobucci, Hibbard, 1999). Because of that, in the process of $\mathrm{B} 2 \mathrm{C}$ relationships creation, very significant is communication with customers, administered in an individual manner (Červenka, Naščáková, Bednárová, Daneshjo, Dudáš-Pajerská, 2018). Such an individual manner of communication is mainly conditioned by technological development which opens up new ways of almost constant communication between companies and consumers.

B2C relationships are also connected to the idea of the relationship between consumers and a brand (consumer brand relationship). It was introduced by Shimpa and Maddena (1988) who wrote that: consumers form relations with consumption objects (products, brands, stores, etc.), which range from feelings of antipathy, to slight fondness, all the way up to what would, in person-person relations, amount to love. Another definition was provided by Kumar (2007) who said that it is the knowledge of: how people make long-term commitments to inanimate objects that they buy and use, as well as help make, sell, and distribute.

As the above-mentioned definitions show, the attribute which differentiates B2C relationships from the consumer brand relationship is the subject of those relationships. In the former type of relationships, it is a company while in the latter it is a brand that refers to the object of consumption. Surely, the relationships between consumers and brand can be connected with $\mathrm{B} 2 \mathrm{C}$ relations. The strength of such a connection will be the consequence of a brand strategy, incorporated by a company.

\section{The structure of $\mathrm{B} 2 \mathrm{C}$ relationships}

Relationships can be considered from two perspectives. The first one assumes the perspective of a consumer and focuses mainly on psychological and emotional aspects, i.e. how do customers feel about their interaction or relationship with a firm or its staff(Barnes, 1997). 
From the second perspective, researchers focus mainly on some aspects of relationships which are perceived in the behavior of and individual (Barnes, 1997; Czepiel, 1990).

To different types of relationships between consumers and companies, we may include (Barnes, 1997): closeness, emotions in relationships, relationship strength and intensity and the duration of relationships. The closeness can be analyzed as a result of a few variables 1. subjective assessment, 2. emotional factors, 3. satisfaction (Snyder, Berscheid, Omoto, 1989) or through the measurement of the frequency of relationships. That element is difficult to be described in a declarative research but it can help to determine the time that is spent in a given relationship. The strength and intensity of relationships are visible in lower vulnerability to some negative impulses and bigger possibility to continue the relationship in the future (Barnes, 1997). The longer time of a relationship can positively impact closeness.

According to Mitręga (2005), for the analysis of relationships we should use variables that exist on the level of seller-buyer relationships with a given intensity. The key feature of a relationship is its strength which can be determined by (Mitręga, 2005): the duration of a relationship, the intensity of a relationship (number of contacts), customer's satisfaction, comparative reference level (tendency to change one company to another), sellers orientation to a customer, seller's expertise and the customer's engagement (emotional attitude).

In order to describe consumers-brand relations Keller (2001) proposed a two-dimensional approach, i.e. intensity that is a consumer psychological bond with the brand and second, an activity that is engendered by consumer loyalty (Ghani, Tuhin, 2016). A bigger number of components concerning relationships with a brand was used by Fritz and Lorenz (2010) and included: interdependence, relationship duration, satisfaction, brand commitment, actual behavior, equity, brand trust, passion and intimacy.

\section{Consumer's engagement}

As brands started to focus on a more relational perspective, a brand's value results from external relationships namely brand-consumer relationships (Fernandes, Moreira, 2019). Therefore, the problem of consumer engagement is closely connected to relationships marketing and based on the conception of service dominant logic proposed by (Vargo, Lusch, 2004, 2008). In this approach we can see a lot of pressure put on non-material resources, co-creation of value and relationships between company/brand and consumers (Prahalad, Ramaswamy, 2004). The term"engagement" can be found in many research papers focusing on marketing, consumer behavior and brand management (Brodie, Hollebeek, Jurić, Ilić, 2011). The definition 
of consumer's engagement includes both economic and management aspects which was proposed by Patterson, Yu and Ruyter (2006). According to those authors, a consumer's engagement are: physical, cognitive and emotional elements in the relationship with a services organization. A similar definition of consumer engagement was provided by Vivek, Beatty and Morgan (2012) who said that it is the intensity of the participation of an individual and the connection between an offer and actions taken by a company, that were started by a consumer or the company itself. A three-element construction of consumer engagement was also highlighted by Hollebeek and Chen (2014) who pointed cognitive, emotional and behavioral investment in relationships with a brand. A different approach was used in the paper by Gummerus, Liljander, Weman and Pihlström (2012), where consumer engagement was defined as the set of behaviors expressed in a relationship with a company. The behavioral approach was also used in the paper by van Doorn et al. (2010) in which it was assumed that consumer engagement is a behavioral activity focused on a brand, which exceeds only a purchase and is driven by some motivational factors.

Such an approach includes a classical set of three components, which lately has been complemented with a social aspect, focusing on the consumers' influence on relationships between different consumers and a brand (Heinonen, 2018; Vivek et al., 2012; Witczak, 2018). Because of the communication possibilities, the social aspect of engagement is used for the analysis of informational and promotional actions taken with the use of social media.

In the research on consumer engagement we often show the connection between those definitions with other theoretical constructions in marketing, such as participation and involvement in organizations that try to engage consumers, which is reflected in trust, perceived value, recommendations, brand loyalty and participation in a community connected with a brand. In such a way, consumer engagement in a brand was described in the paper by Vivek et al. (2012) where the author pointed a one-directional connection between engagement and its consequences. Bowden (2009) treats consumer engagement as a construct composed of rational and other components which lead to making new or repetitive purchase decisions. Such an approach is much more typical for the services market than the material products market.

Consumer brand engagement have a significant role in building increasingly experiential relationships with consumers (Dessart, Veloutsou, Morgan-Thomas, 2016) and implies a deeper, relationship-based level for loyalty development. Engagement refers to a broader relational, multidimensional concept "comprising cognitive, emotional, and/or behavioral dimensions which is more complex than the concept of satisfaction typical for the transactional approach (Fernandes, Moreira, 2019). 
This short overview of papers describing consumer engagement shows that there are two different approaches to the analysis of that issue, which is the result of its sophisticated structure. In the first approach, some specific components are considered jointly. In the second approach, the main focus was placed on behavioral actions through which consumers show their engagement. It means that they can be treated as an indicator. It has some important scientific implications, because the identification of behaviors is easier than the identification of knowledge or affective elements.

\section{The issue of consumer engagement in the context of food markets}

Although the issue of consumer engagement is an important area of scientific work, there is less interest in this field in the context of food markets. Searching for "Consumer engagement" for the years 2000-2019 in the Web of Science database returns 3,918 results (including 3,233 scientific articles). After adding the word "food" to the search parameters, the number drops to 279 results (including 241 scientific articles). ${ }^{3}$ This may be due to the fact that many products that fall into the category of food products are frequently purchased goods, in which case we are dealing with a simplification of the purchasing model and its routine. On the other hand, however, in each of the sub-segment food markets, which include the conventional distribution and alternative distribution market (Gazdecki, 2015), we deal with a large product variety, diverse attitudes and expectations of consumers, which create space for brand development and thus creating consumer engagement. For this reason, the analysis of consumer relations and engagement to food product brands is an important research area due to the possibility of solving scientific problems and providing recommendations for business practice (Gazdecki, Goryńska-Goldmann, 2018).

When analyzing papers on consumer engagement in relation to food products, four main areas can be distinguished. The first area concerns retail trade. In this area, engagement is often understood as loyalty to a commercial unit. For example, Molina, Martín, Santos and Aranda (2009) considered the impact of the perceived quality of the overall customer service on the loyalty of customers. As service components, the researchers adopted queue waiting time, perceived quality of products, and the atmosphere of the store. The problem of shaping loyalty with the use of a shopping loyalty card program was discussed by Arrondo, Berné, Múgica and Rivera (2002). The quality of the commercial unit service can be considered a certain thematic axis around which research problems arise. For example, Choudhary and Singh (2017),

\footnotetext{
3 Web of Science, accessed October 2019.
} 
considering the factors favoring the engagement of young customers of trade units, stated that the quality of service on the part of the shop staff is more important than the quality of the products. In turn, Lund and Marinova (2014), based on data from five trading companies, stated that investing in the quality of service in the store and direct marketing (e.g. point of sales activities) increases the company's profit, but that this effect is not immediate.

The second important thematic area are works devoted to the food service sector. If we treat this sector as one of the food distribution channels, it can be assumed that it has the greatest potential to generate value for customers among all distribution channels that provide food products to consumers (Gazdecki, 2015). Many works combining the issues of consumer engagement and the gastronomy sector consider the issue of the comprehensiveness of the gastronomic product and its role in creating consumer engagement. Olsen and Aaslyng (2007) propose, for example, a new model of creating a gastronomic product (Meal Composition Approach), which is based on the interaction between meal components, and to a lesser extent on the ingredients themselves. The authors indicate that the use of this model is conducive to increasing customer satisfaction and loyalty. Another problem raised is the choice of the products in gastronomy, especially the importance of components forming the meal itself and the circumstances in which it is consumed, which is a reference to the multidimensional structure of the gastronomic product (Edwards, Gustafsson, 2008; Meiselman, 2008). Research indicates that the atmosphere and shopping situation may have a greater impact on creating consumer satisfaction and engagement than product components (Ahlgren, Gustafsson, Hall, 2004). Correia, Moital, Da Costa and Peres reached similar conclusions (2008), indicating that the total experience and customer satisfaction is determined by the combination of the offer of meals, the relation of their quality to price and the atmosphere of the place. Possible strategies for creating consumer engagement in the event of catering businesses entering new markets have been discussed by Lee, Lee and Kim (2016) who considered cultural differences, economic differences and the degree of integration with the country of origin (global connectedness distance).

Another issue is related to the purchasing process and tools that build consumer experience while influencing their decisions. The development and widespread availability of mobile technologies offer many opportunities to build consumer engagement. One example would be various types of mobile applications that can be conducive to the purchase of healthy products (Ball, Mouchacca, Jackson, 2014; Flaherty, McCarthy, Collins, McAuliffe, 2019). Such tools generate sales, but also influence consumer awareness and promote their health-promoting behavior (Dunford et al., 2014). Studies on the purchasing process are also of a more general 
nature and relate, for example, to the impact of brand experience on purchasing decisions for food products (Risitano, Romano, Sorrentino, Quintano, 2017) or the relationship between consumer awareness and their purchasing decisions (Blake, Bisogni, Sobal, Devine, Jastran, 2007).

The fourth type of studies should include those in which the authors' attention is focused on a specific category of food products, in which various components of consumer engagement are considered. The development of consumer health-promoting trends and the food market associated with them (Agnes Kiss, Kiss, Popovics, Szakaly, 2018) caused the food described as healthy and functional to be a frequent subject of these studies. Karstens and Belz (2006) analyze how to overcome consumer skepticism and create their confidence in healthy and functional products through activities focused on brand image development and proper product labeling. The problem of creating trust in relation to brands was also raised by Tung-Lai Hu, Cheng Ying Chang, Wen-Chueh Hsieh and Kuan-Hua Chen (2010) who focused on so-called healthy food, and Kumar and Polonsky (2019) who concentrated on organic products. Caspi, Pelletier, Harnack, Erickson and Laska (2016) considered the practices of commercial enterprises related to maintaining inventories of health products and their impact on consumer purchasing behavior. The problem of consumer confidence and the relationship between levels of awareness, trust and satisfaction was the subject of analyzes carried out by Herrera and Blanco (2011) regarding products with a protected designation of origin.

As it results from the above works devoted to product categories, they have been distinguished based on certain specific product properties (health-related products, organic products with a protected designation of origin), which generates the problem of consumer confidence in a particular property. A separate problem may be the issue of engagement in relation to products isolated according to the commodity criteria, e.g. meat, dairy products, etc. This type of approach was used in this study.

\section{Methodological approach}

The data necessary for the preparation of this study was collected in an interview survey. The direct interviews were conducted with consumers living in Wielkopolska. The fieldwork was carried out in the spring of 2018 among 200 participants. The respondent sampling was 
nonrandom; however the structure of the research sample reflected the structure of the general population by gender and age. ${ }^{4}$

The product category that was subjected to analyses was milk based desserts. The category had been selected for its wide variation of brands, as well as the high frequency and commonness of purchasing. Many milk based dessert producers have strong, well-known and liked brands that provide a basis for the creation of relationships with consumers. The research subject was the consumers who declared the consumption of milk based desserts and the object of analyses was consumers' brand engagement.

It was assumed that consumers' brand engagement is reflected in the behaviours that include four categories:

1. Spending private time (not connected with professional activity) on collecting information or contact with a brand.

2. Use of social media for brand communication and participation in promotional events.

3. Loyalty to the brand (repeated purchase).

4. Willingness to recommend a given brand's products to other consumers.

Each behaviour category was linked with several assigned questions from the questionnaire. Then each answer provided by the respondents was scored. The list of questions and the scores linked to the particular answers are presented in Table 1.

Table 1. Detailed questions on consumers' brand engagement and the values of engagement scores

\begin{tabular}{|c|c|c|}
\hline $\begin{array}{l}\text { Behaviour } \\
\text { category }\end{array}$ & Detailed questions & Score \\
\hline 1 & 2 & 3 \\
\hline \multirow[t]{3}{*}{$\begin{array}{l}\text { Spending private } \\
\text { time }\end{array}$} & $\begin{array}{l}\text { Do you spend your private time on looking for } \\
\text { information on the above-mentioned brand of milk } \\
\text { based desserts? }\end{array}$ & $\begin{array}{l}\text { Yes }=>1 \\
\text { No }=>0\end{array}$ \\
\hline & $\begin{array}{l}\text { How often do you look for information on indicated } \\
\text { brand of milk based desserts? }\end{array}$ & $\begin{array}{l}\text { Once a month and more often }=>1 . \\
\text { More rarely than once a month }=>0\end{array}$ \\
\hline & $\begin{array}{l}\text { How much time do you spend each time on looking for } \\
\text { information on selected brands of milk based desserts, } \\
\text { please give an approximate time in minutes? }\end{array}$ & $\begin{array}{l}\text { Amount of time larger than the average } \\
\text { declared by respondents }=>1 \text {. } \\
\text { Amount of time smaller than the } \\
\text { average declared by respondents }=>0\end{array}$ \\
\hline
\end{tabular}

\footnotetext{
4 Sample structure by age categories was as follows: $18-24$ years: $8 \% ; 25-34$ years: $21 \%$; $35-44$ years: $17 \%$; 45-54 years: $15 \%$; 55-64 years: $19 \%$; 65 years and more: $23 \%$.
} 


\begin{tabular}{|c|c|c|}
\hline 1 & 2 & 3 \\
\hline \multirow{5}{*}{$\begin{array}{l}\text { Use of social } \\
\text { media and } \\
\text { participation } \\
\text { in promotional } \\
\text { events }\end{array}$} & $\begin{array}{l}\text { Have you participated in any loyalty programs of the } \\
\text { previously indicated brands of milk based desserts? }\end{array}$ & $\begin{array}{l}\text { Yes }=>1 \\
\text { No }=>0\end{array}$ \\
\hline & $\begin{array}{l}\text { Have you participated in any contests organized by } \\
\text { milk based dessert producers? }\end{array}$ & $\begin{array}{l}\text { Yes }=>1 \\
\text { No }=>0\end{array}$ \\
\hline & $\begin{array}{l}\text { Have you used any information hubs of the producers } \\
\text { of selected milk based desserts? }\end{array}$ & $\begin{array}{l}\text { Yes }=>1 \\
\text { No }=>0\end{array}$ \\
\hline & $\begin{array}{l}\text { Have you encountered any YouTube channels } \\
\text { of the indicated brands of milk based desserts? }\end{array}$ & $\begin{array}{l}\text { Yes }=>1 \\
\text { No }=>0\end{array}$ \\
\hline & $\begin{array}{l}\text { Do you observe any fan pages of selected brands } \\
\text { of milk based desserts on Facebook, Instagram etc.? }\end{array}$ & $\begin{array}{l}\text { Yes }=>1 \\
\text { No }=>0\end{array}$ \\
\hline \multirow[t]{2}{*}{ Brand loyalty } & $\begin{array}{l}\text { Did you buy indicated brands of milk based desserts } \\
\text { in the past? }\end{array}$ & $\begin{array}{l}\text { Yes }=>1 \\
\text { No }=>0\end{array}$ \\
\hline & $\begin{array}{l}\text { Are you going to buy any of the indicated brands } \\
\text { in the future? }\end{array}$ & $\begin{array}{l}\text { Yes }=>1 \\
\text { No }=>0\end{array}$ \\
\hline $\begin{array}{l}\text { Willingness } \\
\text { to recommend }\end{array}$ & $\begin{array}{l}\text { How likely is that you would recommend the milk } \\
\text { based desserts of the indicated brands to your friends? }\end{array}$ & $\begin{array}{l}\text { Respondent classified as promoter } \\
\Rightarrow>1\end{array}$ \\
\hline
\end{tabular}

Source: own study.

When defining consumers' engagement, there was the engagement total score prepared that was the sum of the points resulting from the answers to individual detailed questions. The higher engagement results were in the higher total score. Spending private time could give each respondent a maximum of 3 points. For actions and social media, each confirmed activity resulted in getting one point (maximum value 5 pts). Brand loyalty was defined on a basis of declarations on purchases in the past and declared willingness to keep buying in the future (maximum value $2 \mathrm{pts}$ ). Willingness to recommend a brand was defined by the NPS index. Each consumer who under the adopted methodology of the NPS index (Reichheld, 2004) was classified as a "promoter", i.e. individuals who were willing to recommend a brand to other consumers, was given 1 point. The maximum value of engagement total score is 11 .

\section{Results and discussion}

In this study, consumer engagement with dairy product brands is considered at the behavioral level and relates to behaviors that result from a strong brand relationship. As an engaged consumer is considered one whose engagement total score is $>0$.

The brands that were most often chosen by consumers to the group of the three best were chosen for the analysis of consumer engagement. In this way, the brands that were most strongly preferred by the respondents were selected, and further analyzes were conducted among persons indicating a given brand as one of the best. 
To facilitate the interpretation of the results, brands have been ranked according to a decreasing share of engaged consumers (Table 2). Significant differences can be noticed in this respect - the consumer engagement score in relation to brands 4 and 6 is significantly higher compared to other brands. Based on this score, two categories of brands were determined: with high and low consumer engagement, and then the other analyzed indicators were averaged within each group, which allowed to better illustrate the differences between the groups. Additionally, engagement level was linked to brand awareness. What was found, brands with a higher level of engagement had at the same time a lower level of awareness assessed for the whole sample. Comparing the various degrees of consumer engagement, it can be seen that both groups differ on a large degree in terms of the time spent on the social media sites of a particular brand. The propensity to recommend based on the participation of individuals belonging to the promoters group is also much higher. There were no differences in terms of loyalty - it is common in both groups.

Table 2. Selected indicators of brand engagement and engagement total score for the analyzed brands

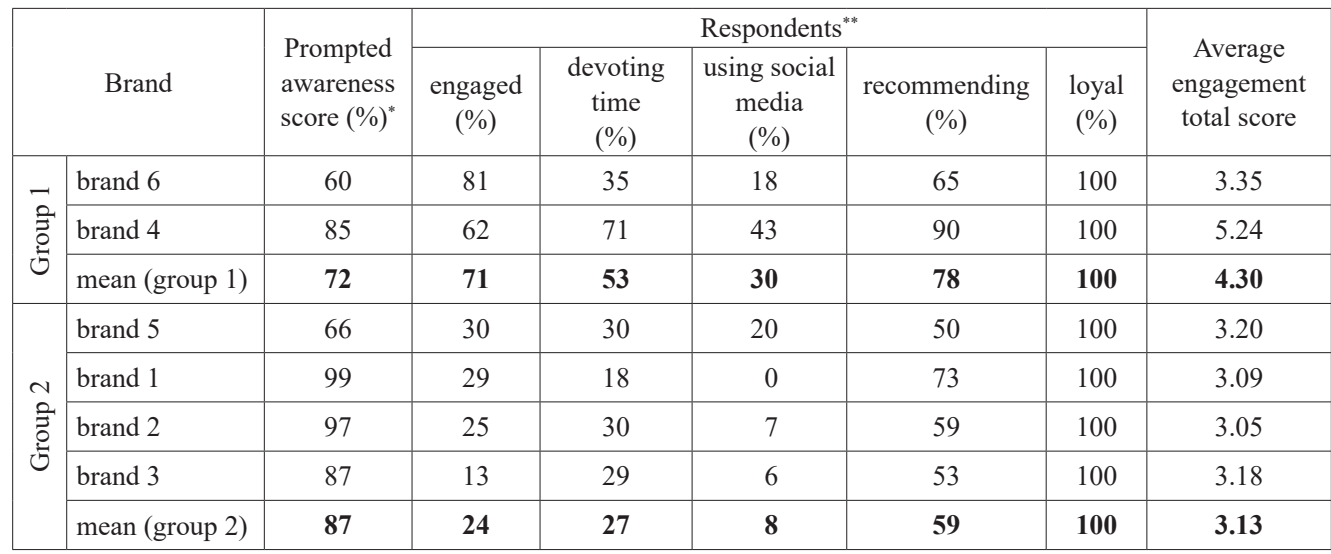

* Based on the declarations of all respondents.

${ }^{* *}$ Based on the declarations of respondents who preferred particular brand.

Source: own study.

The engagement of the surveyed consumers towards dairy products was most evident in terms of loyalty. As many as $75 \%$ of respondents declared that they bought previously or intend to continue buying dairy products of the brand, which they indicated as one of the three preferred. The propensity to recommend can also be considered high. Less than half of the respondents $(46 \%)$ belonged to the promoters category (determined according to the NPS 
methodology). Considerably lower consumer engagement was found for behaviors that require additional activity from them. $30 \%$ of respondents declared searching for information in their free time, while the frequency of such activities was low (less than once a week) and amounted to 6 minutes at a time. However, the use of social media or participation in loyalty programs was declared by $10 \%$ of respondents. Respondents mainly declared visiting YouTube, the website of a given brand and their fan pages. A single person declaring the use of social media mentioned on average 1.8 communication channels belonging to this group, which means that, for consumers active in social media, it is worth preparing marketing communication based on many communication channels.

The results have both cognitive and practical implications. At the cognitive level, it should be noted that if a brand meets the needs of the consumer and is in the basket of preferred brands, this is tantamount to obtaining consumer loyalty (which is one of the dimensions of engagement considered in the work, from a behavioral point of view). To create more complete consumer engagement, it is necessary to create systems that allow for more personalized contact with the brand. Social media is a good tool in this regard. The obtained results suggest that providing the consumers with the opportunity to interact with the brand increases their propensity to recommend, which is a necessary condition for creating a reference market.

This has important practical consequences for market penetration strategies for dairy product brands. Obtaining sales growth through distribution and promotional activities may be difficult due to budget constraints, particularly in the case of smaller enterprises. In such a situation, actions aimed at creating a reference market may be more effective, as it will result not only in maintaining consumer loyalty, but also generate growth due to recommendations. Therefore, social media can have a dual role here. Firstly, they can be a platform for communication with the consumer. Secondly, they should create conditions for engaged consumers to assume the function of brand promoters.

\section{Concluding remarks}

The various scale of activity of companies in food markets means that brands present there may be both local and international in nature (Gazdecki, 2015). This is evident, for example, in the market of dairy based desserts analysed in this paper. The results show that higher brand awareness, connected to the brands' market share, does not always translate into stronger engagement considered at the behavioural level. Such results may be the outcome of marketing strategies employed by the examined brands. On the other hand, however, a conclusion can be 
drawn that brands with lower market share may successfully engage their clients, among else by social media activity. The obtained results show that the significant benefit that companies derive from the engagement of consumers is a considerably higher tendency among consumers to recommend products.

A hypothesis may be formulated, to be proved later, that brand strategies that strongly engage consumers may be especially useful in the case of business operating or markets with low spatial reach, as is often the case with food markets. These brands will be able to compete against brands enjoying bigger market shares by engaging consumers and the effect of a reference market resulting from this action.

\section{Limitations and directions for further studies}

Due to the relatively low sample, the presented results should be treated as a preliminary study. However, the study is a foundation to formulate the direction of further research. The hypothesis posited in the concluding part certainly needs to be confirmed, namely that strategies based on consumer engagement may be especially useful for companies with local reach. In the view of development of electronic media, changes in the scope of media consumption and demographic changes, the identification of the possibilities of the broader use of social media and online communication platforms for creating consumer engagement in food markets is an important research direction.

\section{References}

Agnes Kiss, V., Kiss, M., Popovics, P., Szakaly, Z. (2018). Examination of Lifestyle of Health and Sustainability market groups with particular focus on Hungary. In: M. Gazdecki, E. Goryńska-Goldmann (eds.), Relationships on Food Markets - Consumers'Perspective. Wydawnictwo Uniwersytetu Przyrodniczego w Poznaniu.

Ahlgren, M., Gustafsson, I.-B., Hall, G. (2004). Attitudes and beliefs directed towards readymeal consumption. Food Service Technology, 4 (4), 159-169. DOI: 10.1111/j.14715740.2004.00102.x.

Arrondo, E., Berné, C., Múgica, J.M., Rivera, P. (2002). Modelling of customer retention in multi-format retailing. International Review of Retail, Distribution \& Consumer Research, 12 (3), 281-296. DOI: 10.1080/09593960210139634. 
Barnes, J.G. (1997). Closeness, Strength, and Satisfaction: Examining the Nature of Relationships between Providers of Financial Services and Their Retail Customers. Psychology \& Marketing, 14 (8), 765-790. DOI: 10.1002/(SICI)1520-6793(199712)14:8<765::AIDMAR3>3.0.CO;2-C.

Ball, K., Mouchacca, J., Jackson, M. (2014). The feasibility and appeal of mobile 'apps' for supporting healthy food purchasing and consumption among socioeconomically disadvantaged women: A pilot study: K. Ball et al. Health Promotion Journal of Australia, 25 (2), 79-82. DOI: 10.1071/HE13096.

Bendapudi, N., Berry, L.L. (1997). Customer's Motivations for Maintaining Relationships with Service Providers. Journal of Retailing, 73 (1), 15-37. DOI: 10.1016/S00224359(97)90013-0.

Blake, C.E., Bisogni, C.A., Sobal, J., Devine, C.M., Jastran, M. (2007). Classifying foods in contexts: How adults categorize foods for different eating settings. Appetite, 49 (2), 500 510. DOI: 10.1016/j.appet.2007.03.009.

Bowden, J.L.-H. (2009). The Process of Customer Engagement: A Conceptual Framework. Journal of Marketing Theory \& Practice, 17 (1), 63-74. DOI: 10.2753/MTP10696679170105.

Brodie, R.J., Hollebeek, L.D.; Jurić, B., Ilić, A. (2011). Customer Engagement: Conceptual Domain, Fundamental Propositions, and Implications for Research. Journal of Service Research, 14 (3), 252-271. DOI: 10.1177/1094670511411703.

Caspi, C.E., Pelletier, J.E., Harnack, L., Erickson, D.J., Laska, M.N. (2016). Differences in healthy food supply and stocking practices between small grocery stores, gas-marts, pharmacies and dollar stores. Public Health Nutrition, 19 (3), 540-547. DOI: 10.1017/ S1368980015002724.

Červenka, P., Naščáková, J., Bednárová, L., Daneshjo, N., Dudáš-Pajerská, E. (2018). Development Tendency Testing and Success of Marketing Communications. 16th International Conference on Emerging ELearning Technologies and Applications (ICETA), 87-92.

Choudhary, S., Singh, T. (2017). Role of Retail Store Attributes on Store and Customer Engagement in Food Industry. International Journal of Marketing \& Business Communication, $6(3), 1-10$.

Correia, A., Moital, M., Da Costa, C.F., Peres, R. (2008). The determinants of gastronomic tourists' satisfaction: A second-order factor analysis. Journal of Foodservice, 19 (3), 164-176. DOI: 10.1111/j.1745-4506.2008.00097.x.

Czepiel, J.A. (1990). Service Encounters and Service Relationships: Implications for Research. Journal of Business Research, 20 (1), 13-21. DOI: 10.1016/0148-2963(90)90038-F.

Dessart, L., Veloutsou, C., Morgan-Thomas, A. (2016). Capturing consumer engagement: Duality, dimensionality and measurement. Journal of Marketing Management, 32 (5-6), 399426. DOI: 10.1080/0267257X.2015.1130738. 
Dunford, E., Trevena, H., Goodsell, C., Ng, K.H., Webster, J., Millis, A., Goldstein, S., Hugueniot, O., Neal, B. (2014). FoodSwitch: A Mobile Phone App to Enable Consumers to Make Healthier Food Choices and Crowdsourcing of National Food Composition Data. JMIR MHealth and UHealth, 2 (3), e37. DOI: 10.2196/mhealth.3230.

Edwards, J.S.A., Gustafsson, I.-B. (2008). The Five Aspects Meal Model. Journal of Foodservice, 19 (1), 4-12. DOI: 10.1111/j.1745-4506.2007.00075.x.

Emerson, R. (1976). Social Exchange Theory. Annual Review of Sociology, 2, 335-262.

Fernandes, T., Moreira, M. (2019). Consumer brand engagement, satisfaction and brand loyalty: A comparative study between functional and emotional brand relationships. Journal of Product \& Brand Management, 28 (2), 274-286. DOI: 10.1108/JPBM-08-2017-1545.

Fiske, A.P. (1992). The Four Elementary Forms of Sociality - Framework for a Unified Theory of Social Relations. Psychological Review, 99 (4), 689-723.

Flaherty, S.J., McCarthy, M.B., Collins, A.M., McAuliffe, F.M. (2019). A different perspective on consumer engagement: Exploring the experience of using health apps to support healthier food purchasing. Journal of Marketing Management, 35 (3-4), 310-337. DOI: 10.1080/0267257X.2019.1576756.

Fritz, W., Lorenz, B. (2010). Beziehungen zwischen Konsumenten und Marken - Eine empirische Analyse verschiedener Beziehungstypen. Schmalenbachs Zeitschrift für betriebswirtschaftliche Forschung, 62 (4), 366-393. DOI: 10.1007/BF03373675.

Gazdecki, M. (2015). Sektor usług żywieniowych jako kanał dystrybucji żywności. Wydawnictwo Uniwersytetu Przyrodniczego w Poznaniu.

Gazdecki, M., Goryńska-Goldmann, E. (2018). Relationships on Food Markets - Consumers' Perspective. Wydawnictwo Uniwersytetu Przyrodniczego w Poznaniu.

Ghani, N.H.B.A., Tuhin, M.K.W. (2016). Consumer Brand Relationships. International Review of Management and Marketing, 6 (4), 950-957.

Grönroos, C. (1997). From marketing mix to relationship marketing - Towards a paradigm shift in marketing. Management Decision, 35 (3/4), 322.

Gummerus, J., Liljander, V., Weman, E., Pihlström, M. (2012). Customer engagement in a Facebook brand community. Management Research Review, 35 (9), 857-877. DOI: $10.1108 / 01409171211256578$.

Gummesson, E. (1994). Making Relationship Marketing Operational. International Journal of Service Industry Management, 5 (5), 5-20. DOI: 10.1108/09564239410074349.

Gummesson, E. (1997). Relationship marketing as a paridigm shift: Some conclusions from the 30R approach. Management Decision, 35 (3/4), 267. DOI: 10.1108/00251749710169648.

Håkansson, H., Snehota, I. (1995). Developing Relationships in Business Networks. Routledge. Heinonen, K. (2018). Positive and negative valence influencing consumer engagement. Journal of Service Theory and Practice, 28 (2), 147-169. DOI: 10.1108/JSTP-02-2016-0020. 
Herrera, C.F., Blanco, C.F. (2011). Consequences of consumer trust in PDO food products: The role of familiarity. Journal of Product \& Brand Management, 20 (4), 282-296. DOI: 10.1108/10610421111148306.

Hollebeek, L.D., Chen, T. (2014). Exploring positively- versus negatively-valenced brand engagement: A conceptual model. Journal of Product \& Brand Management, 23 (1), 62-74. DOI: 10.1108/JPBM-06-2013-0332.

Iacobucci, D., Hibbard, J.D. (1999). Toward an Encompassing Theory of Business Marketing Relationships (bmrs) and Interpersonal Commercial Relationships (icrs): An Empirical Generalization. Journal of Interactive Marketing (John Wiley \& Sons), 13 (3), 13-33. DOI: 10.1002/(SICI)1520-6653(199922)13:3<13::AID-DIR2>3.0.CO;2-Z.

Karstens, B., Belz, F.-M. (2006). Information asymmetries, labels and trust in the German food market: A critical analysis based on the economics of information. International Journal of Advertising, 25 (2), 189-211. DOI: 10.1080/02650487.2006.11072962.

Keller, K.L. (2001). Building Customer-Based Brand Equity: A Blueprint for Creating Strong Brands.

Kumar, P., Polonsky, M.J. (2019). In-store experience quality and perceived credibility: A green retailer context. Journal of Retailing \& Consumer Services, 49, 23-34. DOI: 10.1016/j. jretconser.2019.02.022.

Kumar, R. (2007). Marketing and Branding: The Indian Scenario. Pearson Education India.

Lee, S., Lee, J.Y., Kim, R.B. (2016). How do economic, cultural, and global-connectedness distances moderate the effect of customers' experiences on their intention to revisit nonindigenous restaurants? Evidence from Korean restaurants. Asia Pacific Business Review, 22 (2), 262-288. DOI: 10.1080/13602381.2015.1071519.

Lund, D.J., Marinova, D. (2014). Managing Revenue Across Retail Channels: The Interplay of Service Performance and Direct Marketing. Journal of Marketing, 78 (5), 99-118. DOI: 10.1509/jm.13.0220.

Meiselman, H.L. (2008). Dimensions of the meal. Journal of Foodservice, 19 (1), 13-21. DOI: 10.1111/j.1745-4506.2008.00076.x.

Mitręga, M. (2005). Pomiar relacji pomiędzy przedsiębiorstwem a konsumentem. Marketing i Rynek, 2, 2-7.

Mitręga, M. (2006). Building strong relationships between services' providers and consumers: Evidence from Poland. Transformations in Business \& Economics, 5 (2), 148-162.

Molina, A., Martín, V.J., Santos, J., Aranda, E. (2009). Consumer service and loyalty in Spanish grocery store retailing: An empirical study. International Journal of Consumer Studies, 33 (4), 477-485. DOI: 10.1111/j.1470-6431.2009.00780.x.

Olsen, J., Aaslyng, M. (2007). The Meal Composition Approach - a new way of optimising the quality of foodservice products. Journal of Foodservice, 18 (4), 133-144. DOI: 10.1111/j.1745-4506.2007.00058.x. 
Patterson, P., Yu, T., Ruyter, K. (2006). Understanding customer engagement in services. Understanding Customer Engagement in Services, 4-6.

Prahalad, C.K., Ramaswamy, V. (2004). Co-creation experiences: The next practice in value creation. Journal of Interactive Marketing, 18 (3), 5-14. DOI: 10.1002/dir.20015.

Reichheld, F.F. (2004). The One Number You Need to Grow. Harvard Business Review, 82 (6), $133-133$.

Risitano, M., Romano, R., Sorrentino, A., Quintano, M. (2017). The impact of consumer-brand engagement on brand experience and behavioural intentions: An Italian empirical study. British Food Journal, 119 (8), 1884-1896. DOI: 10.1108/BFJ-11-2016-0579.

Rynek Wewnętrzny (2010-2020). Warszawa: GUS.

Seremak-Bulge, J. (2015). Możliwe strategie rozwoju polskiego mleczarstwa po zniesieniu kwot mlecznych. Nowy Przeglad Mleczarski.

Sheth, J.N., Parvatiyar, A. (1995). The Evolution of Relationship Marketing. International Business Review, 4 (4), 397-418.

Shimp, T.A., Madden, T.J. (1988). Consumer-Object Relations: A Conceptual Framework Based Analogously on Sternberg's Triangular Theory of Love. Advances in Consumer Research, 15 (1), 163-168.

Snyder, M., Berscheid, E., Omoto, A.M. (1989). Issues in studying close relationships: Conceptualizing and measuring closeness. Review of Personality and Social Psychology, 10, 63-91.

Tung-Lai Hu, Cheng Ying Chang, Wen-Chueh Hsieh, Kuan-Hua Chen (2010). An Integrated Relationship on Brand Strategy, Brand Equity, Customer Trust and Brand PerformanceAn Empirical Investigation of the Health Food Industry. International Journal of Organizational Innovation, 2 (3), 89-106.

van Doorn, J., Lemon, K.N., Mittal, V., Nass, S., Pick, D., Pirner, P., Verhoef, P.C. (2010). Customer Engagement Behavior: Theoretical Foundations and Research Directions. Journal of Service Research, 13 (3), 253-266. DOI: 10.1177/1094670510375599.

Vargo, S.L., Lusch, R.F. (2004). Evolving to a New Dominant Logic for Marketing. Journal of Marketing, 68 (1), 1-17. DOI: 10.1509/jmkg.68.1.1.24036.

Vargo, S.L., Lusch, R.F. (2008). Service-dominant logic: Continuing the evolution. Journal of the Academy of Marketing Science, 36 (1), 1-10.

Vivek, S.D., Beatty, S.E., Morgan, R.M. (2012). Customer Engagement: Exploring Customer Relationships Beyond Purchase. Journal of Marketing Theory \& Practice, 20 (2), 122 146. DOI: 10.2753/MTP1069-6679200201.

Witczak, O. (2018). Wskaźniki zaangażowania konsumenta wobec marki w mediach społecznościowych. Prace Naukowe Uniwersytetu Ekonomicznego we Wrocławiu, 526, 69-78. 